\title{
Alpha-2 antiplasmin-associated aortic valve thrombus presenting as a STEMI in a patient with Graves disease
}

\author{
Robert Kowtoniuk, ${ }^{1,2}$ Nathaniel Eldredge, ${ }^{2}$ Raghuveer Puntagunta ${ }^{2}$
}

${ }^{1}$ Philadelphia College of Osteopathic Medicine, Philadelphia, Pennsylvania, USA ${ }^{2}$ Geisinger Medical Center, Danville, PA

\section{Correspondence to} Mr. Robert Kowtoniuk, rkowtoniuk@gmail.com

Accepted 5 September 2018

\section{DESCRIPTION}

A 36-year-old Caucasian woman with a medical history of Graves disease presented to the emergency department with typical chest pain, and she was found to have a ST-elevation myocardial infarction (STEMI) via ECG and elevated troponins. Emergent cardiac catheterisation revealed distal blockages in the left anterior descending artery and second obtuse marginal artery (figure 1A,B). After distal balloon angioplasty, the decision was made to further treat the patient medically and discharge home after clinical stability was achieved. She was readmitted 2 days later for new onset of palpitations with up-trending troponins. Laboratory tests were significant for a low thyroid-stimulating hormone of $<0.01 \mu \mathrm{LU} / \mathrm{mL}$ (reference range: $0.27-4.2 \mu \mathrm{LU} / \mathrm{mL}$ ), and elevated free T4 of $4.02 \mu \mathrm{LU} / \mathrm{mL}$ (reference range: $0.9-1.7 \mathrm{ng} / \mathrm{dL}$ ), free $\mathrm{T} 3$ of $4.8 \mathrm{pg} / \mathrm{mL}$ (reference range: $2.5-4.3 \mathrm{pg}$ / $\mathrm{mL}$ ) and a thyroid stimulating immunoglobulin of 386 (reference range: $<140 \%$ baseline). She was immediately started on both methimazole $20 \mathrm{mg}$ and potassium iodine oral solution (SSKI). Further workup revealed the patient's Graves disease had been undertreated for the past several months. The patient stabilised shortly after commencing treatment. As a result of the patient's relatively young age, current hyperthyroid state and negative cardiovascular disease history, an exploration for a potential embolic cause for the patient's STEMI was initiated. A transoesophageal echocardiography discovered two globular sessile echodensities on the surface of the non-coronary cusp of the aortic value (figure 2). Due to the increased risk of a repeat embolic event, she underwent urgent cardiothoracic surgery for excision of the aortic masses which were found to be organised thrombi. An extensive hypercoagulable work-up was negative except for an elevated alpha-2 antiplasmin (a2AP) of 195\%

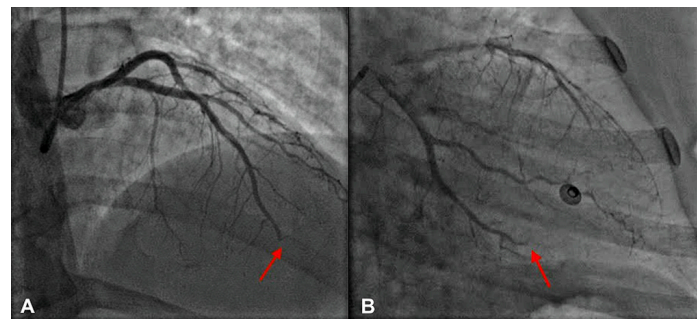

Figure 1 Coronary angiogram. (A) Left anterior descending distal blockage (arrow). (B) Second obtuse marginal artery blockage (arrow).

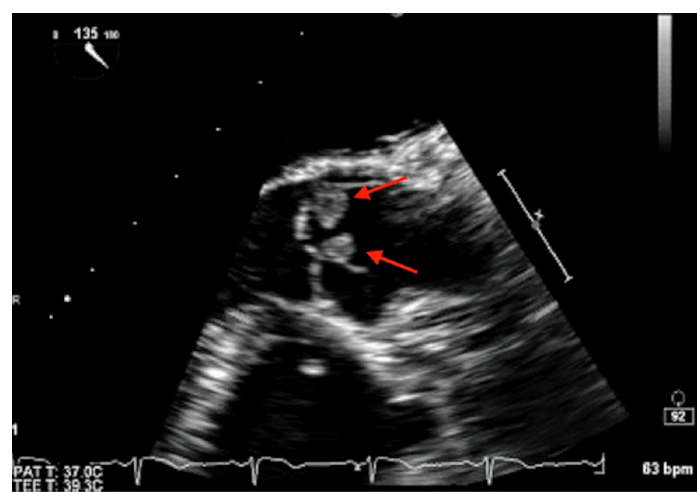

Figure 2 Transoesophageal echocardiography of two globular sessile echodensities $(7 \times 6 \mathrm{~mm}$ and $6 \times 4 \mathrm{~mm}$; arrows) on the aortic surface of the noncoronary cusp.

(reference range: 86\%-156\%). Her recovery was uncomplicated, and she was discharged home with propranolol, methimazole, aspirin, SSKI and warfarin with close follow-up with cardiology and haematology.

Graves disease is the most common cause of hyperthyroidism. The increased production of thyroid hormone is known to place patients with this condition at an increased risk of thromboembolic events. ${ }^{1}$ While the exact cause of this is not completely understood, several mechanisms are thought to be involved. $^{12}$ The unusual cause of a STEMI in this case is believed to be due a hypercoagulable state in the setting of hyperthyroidism. Thus, leading to the formation of an aortic valve thrombus and a subsequently induced embolic STEMI. It has been previously suggested that an elevation in thyroid hormones can cause an increased synthetic capacity of the liver and resultant overproduction of procoagulant proteins, such as a2AP. ${ }^{1-3}$ The protein a2AP is known to stabilise clots by inactivating plasmin, thus serving to inhibit clot lysis. In this case, with the other unremarkable hypercoagulable studies, we believe the hyperthyroid state contributed to the elevated a $2 \mathrm{AP}$ level which may have led to the suppression of the natural clot-breaking mechanisms of plasmin. Of note, once the hyperthyroidism was successfully treated, the elevated a2AP level in our patient recovered as well. Although rare, Graves disease and a2AP has been associated with cerebrovascular thromboembolism. ${ }^{34}$ However to our knowledge, this is the first reported case where a2AP was found to be associated with a STEMI. Moreover, its association with Graves disease offers a potential explanation and area of investigation 
into the pathogenesis of thrombus formation in hyperthyroidism. Further research is needed to fully understand the role a2AP has in the complexities of haemostasis as it may provide a potential space for therapeutic intervention. In addition, this case highlights an important consequence to be aware of in patients with undertreated Graves disease. We recommend regularly scheduled thyroid function testing and close follow-up to monitor similar patients.

\section{Learning points}

- Graves disease is a the most common cause of hyperthyroidism worldwide.

- Although not fully understood, a potential consequence of Graves disease in the setting of hyperthyroidism is a hypercoagulable state.

- An elevation of alpha-2 antiplasmin provides a possible explanation for hypercoagulation and thrombus formation in the setting of hyperthyroidism.
Contributors RK and RP worked on the original concept and design of the manuscript. RK wrote the draft and image formatting. NE collected and organized the images.

Funding The authors have not declared a specific grant for this research from any funding agency in the public, commercial or not-for-profit sectors.

Competing interests None declared.

Patient consent Obtained.

Provenance and peer review Not commissioned; externally peer reviewed.

\section{REFERENCES}

1 Erem C. Thyroid disorders and hypercoagulability. Semin Thromb Hemost 2011;37:017-26.

2 Squizzato A, Romualdi E, Büller HR, et al. Clinical review: thyroid dysfunction and effects on coagulation and fibrinolysis: a systematic review. J Clin Endocrinol Metab 2007:92:2415-20.

3 Hermans E, Mariën P, De Deyn PP. Sinus sigmoideus thrombosis secondary to graves' disease: a case description. Case Rep Neurol 2011;3:203-9.

4 Reed GL, Houng AK, Wang D. Microvascular thrombosis, fibrinolysis, ischemic injury, and death after cerebral thromboembolism are affected by levels of circulating $\alpha 2$ antiplasmin. Arterioscler Thromb Vasc Biol 2014:34:2586-93.

Copyright 2018 BMJ Publishing Group. All rights reserved. For permission to reuse any of this content visit

http://group.bmj.com/group/rights-licensing/permissions.

BMJ Case Report Fellows may re-use this article for personal use and teaching without any further permission.

Become a Fellow of BMJ Case Reports today and you can:

- Submit as many cases as you like

- Enjoy fast sympathetic peer review and rapid publication of accepted articles

- Access all the published articles

Re-use any of the published material for personal use and teaching without further permission

For information on Institutional Fellowships contact consortiasales@bmjgroup.com

Visit casereports.bmj.com for more articles like this and to become a Fellow 